\title{
Schools or Pools of Democracy? A Longitudinal Test of the Relation Between Civic Participation and Political Socialization
}

\author{
Erik van Ingen ${ }^{1} \cdot$ Tom van der Meer $^{2}$
}

Published online: 22 March 2015

(C) The Author(s) 2015. This article is published with open access at Springerlink.com

\begin{abstract}
In this contribution we demonstrate how the usage of panel data offers possibilities for testing new hypotheses in a research tradition with a long history in political science. Focusing on citizens' transitions in and out of voluntary associations, we tested four possible explanations for the well-documented correlation between civic engagement and political socialization. Two are due to self-selection effects (pools of democracy), and two are due to socialization effects (schools of democracy). Our analyses offer little support for the idea of voluntary associations playing a major role in political socialization processes: our latent growth curve models showed no or very little increase of political discussion, interest, efficacy, and action among those who became actively involved in voluntary associations. In contrast, we found convincing evidence for our pools-of-democracy hypotheses, and the self-selection turns out to be a double-edged sword: politically engaged citizens are more likely to join voluntary associations and less likely to leave them. These findings challenge the conclusions of many studies based on cross-sectional data.
\end{abstract}

Keywords Voluntary association · Volunteering · Civic engagement · Political interest $\cdot$ Political action

Electronic supplementary material The online version of this article (doi:10.1007/s11109-015-9307-7) contains supplementary material, which is available to authorized users.

Erik van Ingen

e.j.vaningen@uvt.nl

Tom van der Meer

t.w.g.vandermeer@uva.nl

1 Department of Sociology, Tilburg University, Warandelaan 2, 5000 LE Tilburg, The Netherlands

2 Department of Political Science, University of Amsterdam, Amsterdam, The Netherlands 


\section{Introduction}

A longstanding tradition in political science considers voluntary associations schools of democracy, which engage their members in politics. Participation in voluntary associations would introduce citizens to politics on a small scale (Van Deth 1997), where they learn to deal with dissimilar others (Putnam 2000), practice civic and organizational skills (Ayala 2000; Baggetta 2009), and become interested in wider societal and political issues (Halpern 2005). Members obtain the abilities (civic skills and political efficacy) and the urge (civic-mindedness and political interest) that further engagement in politics (Lichterman 2005; Myrberg 2011; Quintelier 2013). The modern 'neo-Tocquevillian' interpretation emphasizes that such socializing effects may be expected especially from horizontally-organized leisure organizations like reading groups, choirs, bird watching clubs and bowling teams (Putnam 2000; Baggetta 2009). If associational life functions in the way the schools of democracy theorem argues, voluntary associations would make a fine stepping stone towards citizens' wider democratic engagement. Supportive of this reasoning is the fact that virtually all of the abovementioned studies have found positive correlations between civic participation and political engagement.

However, there are competing explanations for this correlations. An alternative interpretation of this common finding emphasizes associations' ability to draw a politically engaged crowd (see e.g., Armingeon 2007). It is "self-evident that not everyone will have the same inclination to join voluntary associations" (Hooghe 2003), and similarly that not everyone will have the same inclination to participate politically. Underlying individual resources (like time, money or skills) or personality traits (pro-sociality, outgoingness or assertiveness) are likely to stimulate citizens to undertake both civic and political activities. "Rather than schools of democracy, this makes voluntary associations pools of democracy" (Van der Meer and Van Ingen 2009: 303): places that draw a politically engaged crowd rather than places where citizens are trained for politics.

We thus have two rivaling theoretical explanations for the empirical relationship between associational involvement and political engagement. Fifty years of empirical research in this field since Almond and Verba (1965) has provided us with a wealth of evidence that indicates that members of voluntary associations are more politically active and interested than non-members (e.g. Putnam 1993; Verba et al. 1995; Pattie et al. 2004; McFarland and Thomas 2006). However, these crosssectional findings are only weak evidence for the proposition that voluntary associations are schools of democracy. Studies that tried to come up with stricter tests have produced ambiguous evidence: some found encouraging results (e.g. McFarland and Thomas 2006), while others found mixed results (e.g. Sobieraj and White 2004) or discouraging results (Van Deth 2000; Van der Meer and Van Ingen 2009). Quintelier (2013) found political socialization effects among adolescents, but her study was restricted to quasi-political associations.

Although voluntary associations are associated with greater political participation, the causal mechanisms are thus still unclear. The fundamental question remains: Do voluntary associations socialize individuals to become more engaged 
(schools of democracy) or are politically engaged individuals more likely to join these associations (pools of democracy)?

The overreliance on correlations and cross-sectional data have undermined the validity of the conclusions in the literature. The neo-Tocquevillian approach assumes a rather strict causal ordering: associational involvement should causally precede pro-democratic attitudes and political action. A positive relationship is a necessary precondition for the schools-of-democracy effect, but far from sufficient evidence for a causal effect. From cross-sectional studies it is impossible to conclude whether members are politically engaged due to their participation (the socialization effect), whether they joined associations because of their political engagement (reversed causality), or whether the relationship is spurious (e.g. because higher educated individuals are simultaneously more involved in politics and associations). The latter two give rise to pools-of-democracy effects.

A test of both mechanisms requires a stricter research design, employing change models (using latent growth curves) based on panel data, which allow researchers to disentangle schools-from pools-of-democracy effects. We use such an analytical strategy to test the causality of the effect of active involvement in associational life on various political outcomes using representative, four-wave panel data. We contribute to the debate by using the long-requested panel data, but also by taking a rather long time span of 3 years and modeling the effect of changes (participation trajectories) on changes (in political engagement). We test four explanations of the well-documented correlation between civic participation and political engagement. Two explanations constitute pools-of-democracy effects: selective entry in voluntary associations and selective exit of voluntary associations. The other two constitute schools-of-democracy (or socialization) effects: growing political engagement as a result of increased involvement in voluntary associations, andas the opposite side of the same coin-declining political engagement as a result of decreased involvement in voluntary associations.

\section{Theory and Hypotheses}

\section{Schools of Democracy}

The theory about political socialization effects of voluntary associations is welldocumented and summarized in various contributions (e.g. Lichterman 2005; Van der Meer and Van Ingen 2009). Associations are considered to be small-scale learning environments (Van Deth 1997). In associations members gain experience in dealing with dissimilar others (Coffé and Geys 2007; Putnam 2000), which may give rise to overarching identities (Putnam 2000), tolerance toward minority groups (Hooghe and Quintelier 2013), ultimately "cultivating the disposition to cooperate" (Rosenblum 1998). Simultaneously, by taking part in internal activities (such as informal discussions, formal meetings, or editing a newsletter) and external activities (such as contacting or negotiating with public authorities) active members enhance their civic skills and obtain higher levels of efficacy (cf. Ayala 2000; Burns 
et al. 2001; Wollebaek and Selle 2002). Thus, associations would socialize members towards civic attitudes and civic skills.

Evidently, this socialization mechanism of voluntary associations is unlikely to be unconditional. Two commonly recognized preconditions are (1) active involvement or face-to-face contact with fellow members, and (2) repeated interactions or prolonged involvement. ${ }^{1}$

A first crucial precondition of socialization is active involvement, i.e., undertaking activities or voluntary work with fellow members of the organization. Various authors have convincingly argued that passive involvement of an association (constrained to donating money, checkbook membership, or reading news letters or magazines) should not affect the likelihood of becoming politically involved (e.g. Putnam 2000; Skocpol 2003). Few effects are to be expected from passive involvement, as the "social spiral" requires members to get into contact with each other (Lichterman 2005). Although passive members could be socialized by reading news letters or by identifying with presupposed associational norms (Selle and Stromsnes 2001; Wollebaek and Selle 2002), such socialization effects of passive involvement should be very small compared to socialization effects related to active involvement. Hence, we will focus our analyses on active involvement in voluntary associations.

Although there is a lack of understanding of the theoretical mechanisms that account for the presumed socialization effect (Mondak and Mutz 1997; Stolle 2001; Baggetta 2009), it is evident that socialization by voluntary associations can only occur after an extended period of involvement (Stolle 1998). Shortly after joining a voluntary association, new members become acquainted with the activities, ideas and norms within that association. The socialization process starts when an individual becomes involved in formal and informal conversations with fellow participants. The theoretical implication of this is that the socialization effect should increase over time, and it probably takes at least several months before these effects begin to manifest themselves. On the other hand, it is self-evident that at some point the marginal socialization effect of extended membership should diminish. Once members have been exposed to the "voluntary association treatment" long enough, they will reach a point where it is no longer possible to acquire additional civic skills or further strengthen democratic attitudes. Therefore, we take into account length of participation period in our analyses (by looking at different "participation transitions"; see below).

Although the schools-of-democracy literature tends to focus on pro-democratic socialization as a one-way street, it is not self-evident that the effects of socialization remain after citizens stop participating in associational life. Socialization effects may erode when peer pressure stops and skills are no longer maintained. In other words, the principles behind the socialization mechanism imply

\footnotetext{
${ }^{1}$ One may consider other preconditions. A longstanding debate in the literature concerns the type of association that is most conducive to political socialization effects, i.e. leisure organizations (e.g. Putnam 2000; Baggatta 2009) or more political organizations (Foley and Edwards 1996; Burns et al. 2001; Armingeon 2007). We may also point out that not all activities might stimulate relevant political skills and efficacy: executive tasks like bar service, transport, or folding letters are unlikely to provide the same benefits as involvement in decision making processes like chairing a meeting or contacting officials.
} 
that these socialization effects may decay, which is not to say that these socialization effects will necessarily disappear completely.

Although this "desocialization effect" has not been tested before, several studies in other areas have shown decay of similar socialization effects. For instance, the effects of civic education among college students were found to weaken progressively within a span of 2 years (Claassen and Monson in press). Similarly, in the very short run electoral campaigns affect voters' attitudes, but both persuasion effects (Hill et al. 2013) and learning effects (Van der Meer et al. in press) decay within days after the end of the campaign. Finally, after a long period of socialization migrants' trust in politics is affected by characteristics of their country of origin, but this socialization effect becomes weaker with the number of years spent in the country of destination (Adman and Stromblad 2013). In other words, desocialization effects occur everywhere.

Scholars have looked for relationships between associational involvement and a range of political outcomes, including involvement in political discussions (Wollebaek and Selle 2002), political interest (Bekkers 2005; Halpern 2005; Van Deth 2006; Quintelier 2013), political efficacy (Myrberg 2011) and-ultimatelypolitical action (Van der Meer and Van Ingen 2009; Schulz and Bailer 2012). We examine these four indicators, although we do not expect these socialization effects to be equally strong. Theoretically, some outcomes should be more sensitive to change and should come earlier in the causal chain than others. It should be easier to socialize members towards political discussions and political interest than to enhance political efficacy and political action. Moreover, changes in the latter probably presuppose preceding changes in interest and/or efficacy. These outcomes differ in the extent to which they require skills, a higher level of civic-mindedness, and connections to the like-minded. Therefore, the four indicators mentioned in the hypotheses below are in order of expected effect size (from the largest to the smallest effect).

H1 Compared to non-participants, those who become actively involved in a voluntary association experience a growth of (a) political discussion, (b) political interest, (c) political efficacy, and (d) political action.

H2 Compared to persistent participants, those who quit being actively involved in a voluntary association experience a decrease of (a) political discussion, (b) political interest, (c) political efficacy, and (d) political action.

\section{Pools of Democracy}

In contrast to the schools-of-democracy argument, the pools-of-democracy idea suggests that members of voluntary associations were already more politically engaged before the joined. The most likely cause for this is that involvement in voluntary associations is (at least partly) determined by factors that are also linked to politics, thereby causing correlation between associational involvement and political engagement (Mondak and Mutz 1997; Hooghe 2003; Van Deth 2006; Armingeon 2007). There is a long list of variables suggested in previous empirical studies which are related to both civic participation and political attitudes and 
behavior (see Van der Meer and Van Ingen 2009). A well-documented example is education: it enhances all modes of associational involvement (membership, participation, volunteering, donations) (Bekkers 2005; Gesthuizen et al. 2008), but it is also a well-known determinant of political interest and action (e.g. Milligan et al. 2004). Another one is personality. Several dimensions of personality have been found to affect civic engagement (Bekkers 2005) as well as political engagement (Mondak et al. 2010). Analyses based on longitudinal data provide better tests for pools-of-democracy hypotheses as well. Although spurious effects can be detected in cross-sectional studies, it remains unclear whether the disturbing factors explain away socialization or self-selection effects.

Another possible reason for the occurrence of pools-of-democracy effects is reversed causality: politically engaged individuals are drawn into voluntary associations because of their political interest or ambitions (cf. Fowler et al. 2011). This is intuitive in the case of quasi-political organizations, such as environmental or humanitarian organizations. It is probably less intuitive in the case of other types of organizations (e.g. religious or leisure organizations).

One indication of pools-of-democracy effects may be that the difference between passive members and non-members is often found to be bigger than the difference between active members and passive members (e.g. Van Deth 2006). This is theoretically inconsistent with the schools-of-democracy hypothesis. It implies (although this is somewhat dependent on the interpretation of passive membership) that the higher levels of political interest and action these members show did not result from interactions and activities within the association (because by way of definition passive members are not involved in these activities).

Similar to the socialization effect, the selection effect can be twofold: the entry into voluntary associations may be selective, but the exit as well. The latter is not often recognized in the literature. Even if there is no relation whatsoever between being politically engaged and becoming a member of a voluntary association, if politically engaged members are more likely to retain their membership this will show up as a correlation between civic engagement and politics in cross-sectional analyses.

H3 Citizens who become actively involved in voluntary associations already show higher levels of (a) political discussion, (b) political interest, (c) political efficacy, and (d) political action before they become actively involved.

H4 Citizens who quit being actively involved in voluntary associations already show lower levels of (a) political discussion, (b) political interest, (c) political efficacy, and (d) political action before they quit being actively involved.

It should be noted that the schools- and pools-of-democracy hypotheses can both hold at the same time. Even if the bulk of the correlations between associational involvement and political attitudes and activities can be attributed to selection effects, subsequent socialization effects may still occur (Hooghe 2003; Iglic 2010; Quintelier 2013). 


\section{Data and Methods}

\section{LISS}

The Longitudinal Internet Studies for the Social sciences (LISS; see www.lissdata. $\mathrm{nl}$ ) is a panel representative of the population of the Netherlands (16 years and older). Together with the US, Canada and the Scandinavian countries, participation rates in the Netherlands are among the highest in the World (e.g. Curtis et al. 2001). This makes it a good case for our current purpose: if schools of democracy are widespread anywhere it should be in these countries.

The LISS panel is designed to follow changes in the life course and living conditions of the panel members. The yearly retention rate is about 90 percent and refreshment samples are drawn to maintain the representativeness of the panel (see Leenheer and Scherpenzeel 2013 for more information). Questionnaires are answered online, and households have been equipped with a computer and/or Internet access when necessary. Monthly questionnaires are answered, taking 15-30 min in total. Most of our data come from the yearly modules Politics and Values, Social Integration and Leisure, and Background Variables. The latter are provided (on a monthly basis) by the household head. Respondents are paid (15 euros per hour) for each completed questionnaire.

\section{Political Discussion, Interest, Efficacy, and Action}

Political discussion has two dimensions and originates from a name generator in the survey. First, respondents were asked: "Most people discuss important things with other people. If you look back on the last 6 months, with whom did you discuss important things?" (max. 5 persons). Subsequently, people were asked how often they discussed political issues with these personal contacts (known as alters in social network studies), with the following answer categories: (1) almost every day, (2) once or twice a week, (3) a few times per month, (4) about once a month, (5) a number of times per year, (6) about once a year, and (7) never. These scores were reversed and recoded to a quasi-continuous measure (number of discussions per year). Subsequently, we took the maximum score across the alters, i.e. when a respondent talks about politics every day with one alter and never with another alter, the "every day" score is assigned. This means that our frequency measure should be interpreted as: respondent talks $\mathrm{X}$ times about politics per year with at least one alter. If respondents indicated that alter $\mathrm{X}$ was a fellow member of an association or organization that person was not included in the count in order to avoid tautology problems. The second dimension of political discussion is the number of alters (sum) with whom politics are discussed (regardless of frequency). Table 1 provides descriptive statistics of the political indicators.

Our measure of political interest is a scale measured through two attitudinal components (self-reported interest in news and in politics) and two behavioral components (reading national and international political news in newspapers) The attitudinal variables' answer categories ranged from 1 (not interested) to 3 (very 
Table 1 Descriptive statistics of political indicators (pooled dataset)

\begin{tabular}{llrrrr}
\hline Variable & N & Mean & SD & Min & Max \\
\hline Political discussion: number alters & 5547 & 2.222 & 1.778 & 0 & 5 \\
Political discussion: (highest) frequency & 5543 & 47.668 & 81.129 & 0 & 300 \\
Political interest & 5509 & 5.599 & 2.419 & 0 & 10 \\
Political efficacy & 5512 & 2.249 & 1.722 & 0 & 6 \\
Political action & 5511 & 0.532 & 0.943 & 0 & 7 \\
\hline
\end{tabular}

interested), the behavioral components ranged from 1 (seldom or never) to 4 (almost always). These 4 variables form very strong and significant Mokken scales in each individual panel wave: H-coefficients range from .70 to .74, and even the weakest item (reading international news) has an $\mathrm{H}_{\mathrm{i}}$ value of minimally .67 .

Political efficacy is a combination of six items: (1) "I am well capable of playing an active role in politics", (2) "I have a clear picture of the most important political issues in our country", (3) "Politics sometimes seems so complicated that people like me can hardly understand what is going on", (4) "Parliamentarians do not care about the opinions of people like me", (5) "Political parties are only interested in my vote and not in my opinion", (6) "People like me have no influence at all on government policies". The answering options were either yes (1) or no (0). Its internal consistency $(\alpha=.65)$ is somewhat downwardly biased because of the fact that the items are dichotomous (auxiliary analyses showed that the tetrachoric interitem correlations are considerably higher than the Pearson's r correlations as used in calculating Cronbach's alpha).

To measure political action (or "unconventional" political participation), respondents were asked the following question: "There are different ways of raising a political issue or of influencing politicians or government. Can you indicate which of the following ways you have exercised over the past 5 years?". We counted the response to the following items (yes/no): (1) calling in radio, television or a newspaper, (2) calling in a political party or organization, (3) participated in a government-organized public hearing, discussion or citizens' participation meeting, (4) contacted a politician or civil servant, (5) participated in a protest action, protest march or demonstration, (6) participated in a political discussion or campaign by Internet, e-mail or SMS, and (7) something else.

Comparing the means of the political indicators across the different waves, we find evidence for period effects on political interest and political activism: both show a modest downward trend. This effect is remarkable, as elections took place in June 2010, directly before the final panel wave. If anything, elections should have boosted interest and activism compared to the pre-election waves. The occurrence of these period effects demonstrates the importance of a research design that incorporates within-person changes and a relevant control group. It should be noted that-in the presence of period effects-the interpretation of socialization or schools-of-democracy effects may change: an effect of active involvement in associations could also mean 'less decline' rather than a 'boost' (i.e. an absolute increase) of interest and activism. 


\section{Active Involvement in Voluntary Associations}

The question about (active) associational participation was similar to the question in the European Social Survey of 2002, and the 1999/2000 survey Citizenship, Involvement and Democracy. Respondents are asked to indicate whether they participated in a list of different voluntary associations in the past 12 months. For each association, respondents reported yes or no to five modes of involvement: (1) no connection, (2) donated money, (3) participated in an activity, (4) member, and (5) performed voluntary work. Whereas modes 2 through 5 all count as associational involvement, we only include (3) participated in an activity and (5) performed voluntary work in our measure of active involvement.

The list of voluntary associations in our analyses consisted of the following: (1) a sports club or club for outdoor activities, (2) a cultural association or hobby club, (3) a trade union, (4) a business, professional or agrarian organization, (5) a consumers' organization or automobile club, (6) an organization for humanitarian aid, human rights, minorities or migrants, (7) an organization for environmental protection, peace organization or animal rights organization, (8) a religious or church organization, (9) a science, education, teachers' or parents' association, (10) a social society; an association for youth, pensioners/senior citizens, women; or friends' clubs, and (11) other organizations that you can freely join. We left out political parties to avoid circular reasoning. ${ }^{2}$ The final measure we used is a categorical variable that included different participation trajectories or transitions in these associations (see "Analytical strategy" section).

\section{Control Variables}

Income is the monthly net household income, divided by 1000 (mean 2.96; SD 4.72). We used the imputed version, provided by the coordinators of the survey (the calculations can be found at the following location: http://www.lissdata.nl/ dataarchive/hosted_files/download/1579). Education is a 6-point scale, ranging from primary education to university degree (mean 3.57; SD 1.48). Occupational status was one of the following three categories: high (higher academic, independent, or supervisory profession), intermediate (intermediate academic, independent, supervisory, or commercial profession), and low (other mental work or manual work). Those without a job were asked about their last job; if respondents never worked their scores are missing. Furthermore, our analyses included controls for age (mean 46.97; SD 15.98) and gender. Finally, personality was measured by the wellknown inventory of the "big-five" personality traits (Goldberg 1992). The control variables were measured at the start of the panel. When values were missing we used the nearest non-missing value (if possible).

\footnotetext{
${ }^{2}$ We had hoped to deepen the analyses with an additional focus on politicized associations such as activist and interest organizations, where socialization processes are more likely to take place (Burns et al. 2001; Armingeon 2007). Unfortunately, the number of transitions becomes too low for fruitful analysis once we try to break down associations by type.
} 


\section{Analytical Strategy}

Our analytical strategy is similar for all four political indicators. Figure A.1 (online Appendix) provides an overview the measurement of our variables. P1 represents the first wave of the questionnaire about politics and values. This module contained the political interest, internal efficacy, and political action variables. S1 represents the first wave of the questionnaire about social integration and this module contained the civic participation variables as well as the indicators of political discussion. We divided respondents into groups according to the participation transitions they reported (questionnaires S1, S2, and S3). The groups that are of substantive interest are listed and labeled in Figure A.1. For example, "incidental joiners" (pattern 010) are respondents who did not participate actively in a voluntary association at S1 (0 meaning not involved), then joined (at least) one between S1 and S2 (1 meaning involved), and subsequently quit between S2 and S3 (0 again).

Our main focus in the interpretation of the results is on the difference between non-participants (pattern 000) and joiners (011) for the entry effects and on the difference between persistent participants (111) and leavers (100) for the exit effects. See Van Ingen and Bekkers (2015) for a similar strategy as well as a discussion about modelling longitudinal effects of multiple memberships. The largest groups are in a stable state, i.e. they are either non-participants ("000"; $29 \%$ ) or persistent participants ("111"; $26 \%$ ). Among the respondents who joined (at least one) voluntary association between waves 1 and 2, around $50 \%$ decided to quit participating again between wave 2 and 3: the groups early joiners (011) and incidental joiners (010) are of roughly equal size (both around $8 \%$ of the sample). The late joiners (001) constitute $7 \%$ of the sample.

We apply latent growth curve models to examine our data (using Stata 13). Based on the four-wave measurement of the political indicators, we estimate a (latent) intercept and (latent) slope of the individual political socialization trajectories of respondents: the slope represents the amount of growth, the intercept represents the initial score (wave 1) on the political indicator. Respondents with other participation transitions (e.g. with missing values) than the ones listed in Figure A.1 were not included in our models. We estimated our structural equation models using "maximum likelihood with missing values" (see StataCorp. 2013). ${ }^{3}$ The advantage of this method is that respondents did not have to complete all four questionnaires to be included in the analyses.

In order to test our pools-of-democracy hypotheses we need to find out whether members were already more politically socialized before they entered an association. This can be tested with our models by comparing the intercepts of the "joiners" with the intercept of "non-participants": as can be seen in Fig. A.1, P1 is prior to joining the association between $\mathrm{S} 1$ and $\mathrm{S} 2$. Additionally, a selection effect may exist with regard to remaining involved in a voluntary association. This can be

\footnotetext{
3 Although the distribution of the political action measure is highly skewed, our models turned out to be robust against different model specification (e.g. other procedures of estimating standard errors or using dichotomized measures as outcome). For frequency of political discussion, we assessed growth curve models with an ordered logit link function (GSEM in Stata13) (see Table 1).
} 
tested by comparing the intercepts of "persistent participants" (111) with "leavers" (100) (the intercepts represent the scores prior to the decision to exit).

In order to test our schools-of-democracy hypotheses, we need to find out whether members became more politically socialized after they joined an association. This can be tested by comparing the growth "curve" (estimated as a linear trend in our models) of the joiners with the growth curve of the nonparticipants. Similarly, desocialization effects are tested by comparing the growth curves of persistent participants" (111) with "leavers" (100).

By comparing participation transition groups we avoid bias caused by period effects (which are present in our data): the non-participants (000) act as a quasicontrol group. Furthermore, we note that the group of "persistent participants" (111) is also of interest, but the interpretation of their scores is not straightforward. If their intercept is different from non-participants, this can reflect both selection and causation (just like in cross-sectional research); when their growth curve is different it may represent a late, or lagged effect (since they had already been participating for an unknown period before we started monitoring them at S1).

\section{Results}

Figure 1 illustrates the average degree of political engagement in each of the four subsequent waves across the theoretically relevant groups of non-participants (000), joiners (011), persistent participants (111), and leavers (100). Some of the differences between the groups in the first wave (black bars) are small. However, the differences between non-participants (000) and persistent participants (111) are often considerable. For instance, the standardized difference in political action between these groups equals $.42(0.78-0.38 / 0.943)$. These differences are the main reason why cross-sectional studies often report intermediate or large correlations between civic engagement and political attitudes and behavior. All five indicators of political engagement suggest pools-of-democracy effects: joiners tend to have somewhat higher scores than non-participants (before they join), leavers somewhat lower scores than persistent participants (before they leave).

If schools-of-democracy effects exist, we would expect that over time political engagement increases among joiners, or at least that their trend is more positive than the trend of non-participants. Figure 1 shows, however, that the trends hardly differ, let alone consistently. It also shows that socialization effects seem more likely in the case of political discussions and political interest than they do in the cases of political efficacy and political action.

Next, we turn to a more formal test, using growth curve models. Table 2 shows the results of our analyses of political discussion, which has two dimensions: the number of alters with whom politics is discussed (or the size of the political network; models I and II) and the frequency of discussion (models III and IV).

First, we look at the effects on the latent intercept variable, which gives us an indication of the extent to which voluntary associations are pools of democracy. The constant in the uncontrolled intercept equation (model $\mathrm{I}: \mathrm{b}=2.001$ ) reflects the average number of alters non-participants discussed politics with. The other 

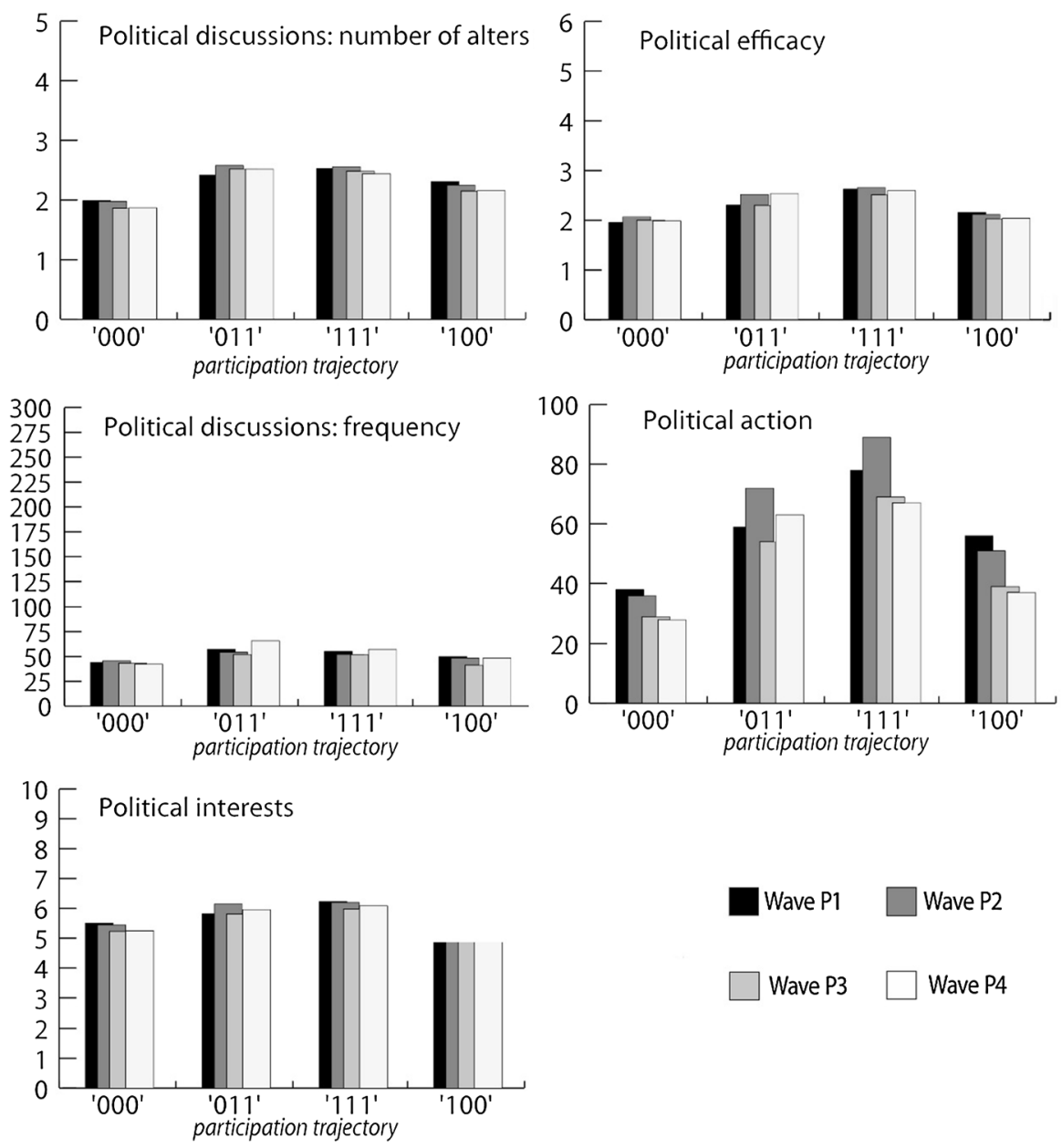

Wave P1 $\square$ Wave P2

Wave P3 $\square$ Wave P4

Fig. 1 Observed differences between transition groups

coefficients reflect the differences between this group and other participation transition groups. In other words, the point estimates of the intercept equation in model I provide the same information as the black bars in Fig. 1, but now accompanied by statistical tests. We find significant, positive differences between the reference group and all three participant groups (Table A.1 in the Appendix shows a complete list of other participation transitions). The significant coefficient of joiners $(b=0.475)$ in model I implies that individuals who decided to join a voluntary association already had a larger political network than non-participants (000) before joining, thereby contributing to the pool of democracy. The difference remained significant after controlling for personality, education, income, occupational status, gender, and age (model II), thereby supporting H3a. Judging from the standardized coefficients (not shown), education $(\beta=.29)$ and openness to 
Table 2 Growth curve models of political discussion (standard errors within parentheses)

\begin{tabular}{|c|c|c|c|c|}
\hline & \multicolumn{2}{|c|}{$\begin{array}{l}\text { Number of alters with whom politics } \\
\text { discussed }\end{array}$} & \multicolumn{2}{|c|}{$\begin{array}{l}\text { (Highest) frequency of political } \\
\text { discussion }^{\mathrm{a}}\end{array}$} \\
\hline & (I) & (II) & (III) & (IV) \\
\hline \multicolumn{5}{|l|}{ Intercept equation } \\
\hline Non-participants (000) & Ref. & Ref. & Ref. & Ref. \\
\hline Joiners $(011)$ & $\begin{array}{l}0.475 * * \\
(0.108)\end{array}$ & $\begin{array}{l}0.299 * * \\
(0.101)\end{array}$ & $\begin{array}{l}0.793 * * \\
(0.176)\end{array}$ & $\begin{array}{l}0.571 * * \\
(0.182)\end{array}$ \\
\hline Persistent participants (111) & $\begin{array}{l}0.557 * * \\
(0.070)\end{array}$ & $\begin{array}{l}0.309 * * \\
(0.065)\end{array}$ & $\begin{array}{l}0.826^{* *} \\
(0.121)\end{array}$ & $\begin{array}{l}0.435 * * \\
(0.124)\end{array}$ \\
\hline Leavers (100) & $\begin{array}{l}0.298 * * \\
(0.087)\end{array}$ & $\begin{array}{l}0.203 * \\
(0.080)\end{array}$ & $\begin{array}{l}0.385^{*} \\
(0.151)\end{array}$ & $\begin{array}{l}0.353 * \\
(0.153)\end{array}$ \\
\hline Constant & $\begin{array}{l}2.001 * * \\
(0.050)\end{array}$ & $\begin{array}{l}1.053 * * \\
(0.151)\end{array}$ & - & - \\
\hline Control variables ${ }^{\mathrm{b}}$ & - & $\mathrm{V}$ & - & $\mathrm{v}$ \\
\hline \multicolumn{5}{|l|}{ Slope equation } \\
\hline Non-participants (000) & Ref. & Ref. & Ref. & Ref. \\
\hline Joiners $(011)$ & $\begin{array}{l}0.079 * \\
(0.037)\end{array}$ & $\begin{array}{l}0.084 * \\
(0.037)\end{array}$ & $\begin{array}{l}0.080 \\
(0.061)\end{array}$ & $\begin{array}{l}0.056 \\
(0.066)\end{array}$ \\
\hline Persistent participants (111) & $\begin{array}{l}0.015 \\
(0.025)\end{array}$ & $\begin{array}{l}0.023 \\
(0.025)\end{array}$ & $\begin{array}{l}0.025 \\
(0.040)\end{array}$ & $\begin{array}{l}0.028 \\
(0.043)\end{array}$ \\
\hline Leavers (100) & $\begin{array}{l}-0.003 \\
(0.033)\end{array}$ & $\begin{array}{l}0.001 \\
(0.033)\end{array}$ & $\begin{array}{l}-0.060 \\
(0.051)\end{array}$ & $\begin{array}{l}-0.058 \\
(0.054)\end{array}$ \\
\hline Constant & $\begin{array}{l}-0.052^{* *} \\
(0.017)\end{array}$ & $\begin{array}{l}-0.175^{*} \\
(0.057)\end{array}$ & $\begin{array}{l}-0.041 \\
(0.032)\end{array}$ & $\begin{array}{l}-0.228 \\
(0.108)\end{array}$ \\
\hline Control variables ${ }^{\mathrm{b}}$ & - & $\mathrm{v}$ & - & $\mathrm{v}$ \\
\hline Observations & 4232 & 4232 & 4232 & 4232 \\
\hline
\end{tabular}

$* p<0.05, * * p<0.01$

${ }^{\text {a }}$ Growth curve models with an ordered logit link function (GSEM in Stata13). Cutpoints were fixed to be similar across the waves. Additional analyses on the separate waves showed deviations from the proportional odds assumption of the ordered logit regression (see Long and Freese 2001). A Brant test showed that the control variables (not shown in Table 2) were mostly responsible for this and therefore they have to be interpreted with caution

b Control variables: personality (big 5), education, income, occupational status, gender, and age

experience $(\beta=.13)$ are the most important explanations of differences in the size of the political discussion network before joining an association (Tables A.1-A.4 in the online appendix show the effects of the control variables).

Persistent participants also have a larger political discussion network than nonparticipants: the difference in model I corresponds to roughly 0.30 standard deviations. Model II shows that at least part of this effect is spurious (coefficient is reduced from 0.557 to 0.309 ). As indicated in the analytical strategy section, and similar to cross-sectional studies, it is not possible to judge whether the difference that remains is due to causation or selection (although the analyses below suggest the latter). 
Auxiliary analyses showed that the difference between persistent participants (111) and leavers (100) was significant $(p=.003)$, as expected in H4a. This difference dropped below significance levels after adding control variables in model II. We conclude that this is a case of double selection: those with larger political discussion networks are more likely to join and less likely to quit. In turn, this can be explained to a large extent by the fact that these individuals have more privileged social positions (most importantly: a higher education) and different personalities (mainly higher scores on openness).

We find similar evidence for our pools-of-democracy argument with regard to the frequency of discussion (models III and IV). The difference between joiners and non-participants was significant in both the controlled and uncontrolled model (supporting $\mathrm{H} 3 \mathrm{a}$ ), although the difference is partly explained by the control variables, again most importantly education and openness to experience. The difference between leavers and persistent participants was significant in the uncontrolled model and non-significant in the controlled model. In other words, those who decide to leave the voluntary association discuss politics less frequently than those who stay (supporting $\mathrm{H} 4 \mathrm{a}$ ), and this can be explained by their social status and personality.

Second, we turn to schools-of-democracy effects. The bottom part of Table 2 provides tests of hypotheses 1a and $2 \mathrm{a}$. If the schools of democracy idea is true then those who joined (011) should show a larger increase in political discussion than those who remain uninvolved (000). The results are inconsistent. Among joiners (011), there is a significantly stronger increase in the number of people with whom politics is discussed than among non-participants (both models I and II). However, there is no such difference when it comes to the frequency of discussion (models III and IV), which makes the support for H1a ambivalent.

There are a few things we have to note. First, the difference between joiners and non-participants is small: it represents a yearly growth of .08 on a variable with an average of 2.22 and SD of 1.78 (see Table 1). Second, since the "growth" of the reference group is negative $(b=-0.052)$-meaning that the size of the political discussion network decreased slightly in the period of the research among nonparticipants - the real growth of the joiners is only $0.027(-0.052+0.079)$. Third, there are other substantive interpretations of the growth effect than socialization: it may (also) indicate a network effect (joiners obtain a larger network).

By contrast, we found no exit effects on political discussion: the differences in the slope of leavers (110) and persistent participants (111) were not significantly different from zero (not shown in the table). This rejects $\mathrm{H} 2 \mathrm{a}$.

With Table 3 we move to political interest. First, we turn to pools-of-democracy effects. Model I shows that joiners already had significantly more political interest than non-participants before they joined an association. This difference is to a large extent due to differences in social status and personality: (model II) after the control variables are entered the difference is no longer significant. The intercept of persistent participants was even higher, but the interpretation of this coefficient is somewhat more ambiguous (as we explained in the "data and methods" section). We also found a pools-of-democracy effect with regard to quitting participation: the difference in intercepts between leavers and persistent participants is significant 
Table 3 Growth curve models of political interest (standard errors within parentheses)
(I)

(II)

\begin{tabular}{|c|c|c|}
\hline & (I) & (II) \\
\hline \multicolumn{3}{|l|}{ Intercept equation } \\
\hline Non-participants (000) & Ref. & Ref. \\
\hline \multirow[t]{2}{*}{ Joiners $(011)$} & $0.465 * *$ & 0.186 \\
\hline & $(0.143)$ & $(0.120)$ \\
\hline \multirow[t]{2}{*}{ Persistent participants (111) } & $0.724 * *$ & $0.256 * *$ \\
\hline & $(0.100)$ & $(0.084)$ \\
\hline \multirow[t]{2}{*}{ Leavers (100) } & -0.105 & -0.092 \\
\hline & $(0.128)$ & $(0.106)$ \\
\hline \multirow[t]{2}{*}{ Constant } & $5.504 * *$ & $3.507 * *$ \\
\hline & $(0.072)$ & $(0.196)$ \\
\hline Control variables ${ }^{\mathrm{a}}$ & - & $\mathrm{v}$ \\
\hline \multicolumn{3}{|l|}{ Slope equation } \\
\hline Non-participants (000) & Ref. & Ref. \\
\hline \multirow[t]{2}{*}{ Joiners $(011)$} & 0.064 & 0.052 \\
\hline & $(0.042)$ & $(0.042)$ \\
\hline \multirow[t]{2}{*}{ Persistent participants (111) } & 0.035 & 0.022 \\
\hline & $(0.026)$ & $(0.027)$ \\
\hline \multirow[t]{2}{*}{ Leavers (100) } & -0.006 & -0.010 \\
\hline & $(0.035)$ & $(0.035)$ \\
\hline \multirow[t]{2}{*}{ Constant } & $-0.122 * *$ & $-0.131 *$ \\
\hline & $(0.020)$ & $(0.067)$ \\
\hline Control variables ${ }^{\mathrm{a}}$ & - & $\mathrm{v}$ \\
\hline Observations & 4232 & 4232 \\
\hline
\end{tabular}

$* p<0.05, * * p<0.01$

a Control variables: personality (big 5), education, income, occupational status, gender, and age

( $p=.000)$, regardless of the inclusion of control variables. This means that we find both types of selection effects and thus consistent support for our pools-ofdemocracy hypotheses ( $\mathrm{H} 3 \mathrm{~b}$ and $\mathrm{H} 4 \mathrm{~b}$ ). Judging from the standardized effects (not shown), the most important determinants of the level of political interest before joining an association are age $(\beta=.40)$, education $(\beta=.21)$, and openness to experience $(\beta=.21)$ (see Table A.2 for the effects of all control variables).

The bottom block of Table 3 again tests socialization effects by showing the differences in growth curves (slopes). As models 1 and 2 show, we find no schoolsof-democracy effects among the groups listed (see Appendix A.2 for a more elaborate list of participation patterns). Thus, we reject H1b. The constant in model I (slope equation) suggests that among non-participants there was a small decrease of political interest $(b=-0.122)$. Finally, we do not find that leaving an association reduces interest: The slope of leavers was not significantly different from the slope of persistent participants $(p=.296)$. Hypothesis $\mathrm{H} 2 \mathrm{~b}$ is thus rejected.

Our analyses of political efficacy in Table 4 show a pattern that is largely similar to the findings among the other indicators. There was a double pools-of-democracy effect: joiners reported higher political efficacy (before) they joined in comparison to non-participants, and leavers reported lower political efficacy (before they left) than persistent participants (the latter difference was significant in both models 
Table 4 Growth curve models of political efficacy (standard errors within parentheses)
$* p<0.05, * * p<0.01$

a Control variables: personality (big 5), education, income, occupational status, gender, and age
(I)

(II)

\begin{tabular}{|c|c|c|}
\hline \multicolumn{3}{|l|}{ Intercept equation } \\
\hline Non-participants (000) & Ref. & Ref. \\
\hline \multirow[t]{2}{*}{ Joiners (011) } & $0.353 * *$ & $0.195^{*}$ \\
\hline & $(0.098)$ & $(0.088)$ \\
\hline \multirow[t]{2}{*}{ Persistent participants (111) } & $0.633 * *$ & $0.366^{* *}$ \\
\hline & $(0.070)$ & $(0.064)$ \\
\hline \multirow[t]{2}{*}{ Leavers (100) } & $0.179 *$ & 0.114 \\
\hline & $(0.087)$ & $(0.076)$ \\
\hline \multirow[t]{2}{*}{ Constant } & $2.009 * *$ & $1.291 * *$ \\
\hline & $(0.048)$ & $(0.142)$ \\
\hline Control variables $^{\mathrm{a}}$ & - & $\mathrm{v}$ \\
\hline \multicolumn{3}{|l|}{ Slope equation } \\
\hline Non-participants (000) & Ref. & Ref. \\
\hline \multirow[t]{2}{*}{ Joiners (011) } & 0.024 & 0.026 \\
\hline & $(0.034)$ & $(0.034)$ \\
\hline \multirow[t]{2}{*}{ Persistent participants (111) } & -0.028 & -0.017 \\
\hline & $(0.023)$ & $(0.024)$ \\
\hline \multirow[t]{2}{*}{ Leavers (100) } & -0.057 & $-0.061^{*}$ \\
\hline & $(0.029)$ & $(0.029)$ \\
\hline \multirow[t]{2}{*}{ Constant } & 0.004 & $0.179 * *$ \\
\hline & $(0.016)$ & $(0.053)$ \\
\hline Control variables $^{\mathrm{a}}$ & - & $\mathrm{v}$ \\
\hline Observations & 4232 & 4232 \\
\hline
\end{tabular}

$(p=.000$ and $p=.002))$. These results strongly support H3c and H4c. Education ( $\beta=.35)$ and openness to experience $(\beta=.21)$ were by far the most important determinants of the level of political efficacy (see online Appendix).

Our analyses of the growth curves in the bottom block of Table 4 provided no support for socialization or schools-of-democracy arguments: none of the effects were significant (H1c is rejected). We also found no exit effect: the difference between leavers and persistent participants was non-significant in both models $(\mathrm{H} 2 \mathrm{c}$ is rejected).

Table 5 shows the results of our analyses with regard to political action and shows again a similar picture. Our findings show clearly that pools-of-democracy effects exist, with regard to both the decision to join a voluntary association and retain involvement. The difference between leavers and persistent participants was also significant in models I and II (both $p=.000$ ). This provides strong support for $\mathrm{H} 3 \mathrm{~d}$ and H4d. Our analyses of the slopes consistently show no evidence of growth of political action after becoming involved in (at least one) voluntary association, and neither did we find a decline of political action after becoming uninvolved. H1d and $\mathrm{H} 2 \mathrm{~d}$ are thus rejected. 
Table 5 Growth curve models of political action (standard errors within parentheses)
(I)

(II)

\begin{tabular}{|c|c|c|}
\hline & (I) & (II) \\
\hline \multicolumn{3}{|l|}{ Intercept equation } \\
\hline Non-participants (000) & Ref. & Ref. \\
\hline \multirow[t]{2}{*}{ Joiners (011) } & $0.258 * *$ & $0.189 * *$ \\
\hline & $(0.059)$ & $(0.058)$ \\
\hline \multirow[t]{2}{*}{ Persistent participants (111) } & $0.454 * *$ & $0.347 * *$ \\
\hline & $(0.041)$ & $(0.039)$ \\
\hline \multirow[t]{2}{*}{ Leavers (100) } & $0.173 * *$ & $0.150 * *$ \\
\hline & $(0.043)$ & $(0.042)$ \\
\hline \multirow[t]{2}{*}{ Constant } & $0.383 * *$ & $0.248 * *$ \\
\hline & $(0.021)$ & $(0.085)$ \\
\hline Control variables ${ }^{\mathrm{a}}$ & - & $\mathrm{v}$ \\
\hline \multicolumn{3}{|l|}{ Slope equation } \\
\hline Non-participants (000) & Ref. & Ref. \\
\hline \multirow[t]{2}{*}{ Joiners (011) } & 0.016 & 0.022 \\
\hline & $(0.021)$ & $(0.021)$ \\
\hline \multirow[t]{2}{*}{ Persistent participants (111) } & -0.020 & -0.012 \\
\hline & $(0.013)$ & $(0.013)$ \\
\hline \multirow[t]{2}{*}{ Leavers (100) } & -0.029 & -0.025 \\
\hline & $(0.015)$ & $(0.015)$ \\
\hline \multirow[t]{2}{*}{ Constant } & $-0.034 * *$ & $-0.078^{*}$ \\
\hline & $(0.008)$ & $(0.033)$ \\
\hline Control variables ${ }^{\mathrm{a}}$ & - & $\mathrm{v}$ \\
\hline Observations & 4232 & 4232 \\
\hline
\end{tabular}

$* p<0.05, * * p<0.01$

a Control variables: personality (big 5), education, income, occupational status, gender, and age

\section{Discussion and Conclusions}

In this study we tried to contribute to a research tradition with a long history in political science, which studies political socialization processes in non-political or quasi-political organizations. Focusing on citizens' transitions in and out of voluntary associations, we tested four possible explanations for the correlation between participation in voluntary associations and political socialization: selective entry and selective exit (pools of democracy), and socialization and de-socialization effects (schools of democracy). This innovative approach was facilitated by nationally representative panel data, in which respondents answer yearly questions about their civic engagement and political attitudes and behavior. These data not only allow better tests of the validity of well-known theories about voluntary associations' role in political socialization, they also force researchers to be more specific about the mechanisms that operate, such as the timing of the effects and possibility of exit effects next to entry effects.

Where does this study leave us? First, it is quite evident from our analyses that voluntary associations do not live up to the lofty ideals of being schools of democracy and agents of political socialization. We found little support for the idea that civic engagement boosts political engagement, and the scarce effects we found 
were small. This does not mean that no single voluntary association exists where members are politically socialized or that there are no groups for which associational involvement leads to more political interest and action. For instance, effects may be stronger among adolescents (McFarland and Thomas 2006; Smith 1999). However, our results do indicate that in a general population and averaged across different types of associations, there is no meaningful, general schools-ofdemocracy effect.

We have considerable confidence in the validity of this conclusion, not only because of the research design of our study (longitudinal analyses based on a large representative sample) but also because of the double test (entry + exist) we introduced. If there is something in the "participation treatment" that boosts political interest and action, this should - in all likelihood-also result in erosion of political interest and action when citizens quit being actively involved. However, both tests fail to support the schools-of-democracy hypothesis.

Second, we looked for evidence of voluntary associations being pools of democracy, attracting politically engaged citizens. For that purpose, we tested whether differences between members and non-members already existed before the former entered a voluntary association. We found vast evidence supporting this idea: most of the correlation between associational involvement and political engagement is due to self-selection effects. This self-selection is a double-edged sword: politically engaged citizens are more likely to join voluntary associations and also less likely to leave them. In turn, these differences can-to a large extentbe attributed to the socioeconomic status, age, and gender of active members.

A few shortcomings of our study need to be discussed. First, the length of the "participation treatment" in our models (1.5 years on average) may be too short, as one of our reviewers suggested. To explore this possibility we ran additional models in which this period was extended to 2.5 years on average (by adding an additional wave). The results were identical: no (significant) difference in the growth curves of those who started participating and those who remained uninvolved. This does not exclude the possibility of effects emerging after 3 or 4 years, but it seems very unlikely that-if schools-of-democracy effects exist-they would not manifest themselves until the third year of participation. Second, our data did not allow us to separate between types of associations (e.g. between those with (quasi-)political aims and those with other aims). Future research may want to examine whether there are special circumstances under which political socialization effects occur. However, our results suggest that-if these circumstances exist-they are likely rare: otherwise, we should have been able to detect them in our more generic test. Third, our measure of political action asked respondents about the past 5 years. This means that within-person change can result from recent changes but also from changes in behavior longer ago. On the other hand, there are numerous studies that show that respondents mainly recall and report recent autobiographical events in surveys (e.g. Bradburn et al. 1987), which is actually an advantage in this case. Nonetheless, we need to be cautious when interpreting the results of our analyses of political action.

Our findings challenge many of the conclusions drawn in cross-sectional studies, also the ones with a more sophisticated theoretical approach of school-of- 
democracy effects, like the idea of a cycle of selection and adaptation (Hooghe 2003; Quintelier 2013), in which-based on the idea of value congruencesocialization effects should be strongest among homogeneous associations with politically engaged members. Our results are also not very promising for this suggested mechanism of political socialization, because even if it exists it did not result in a general, positive participation effect in our analyses. This means that the effect was too small to reach levels of significance in our (large) data set, or that it is counterbalanced by a negative political socialization effect in other kinds of voluntary associations (e.g. intolerant and non-democratic attitudes may also be strengthened by interactions with similar-minded fellow members). In both cases, the overall contribution of voluntary associations to political socialization is very modest at best. Voluntary associations may (cf. Fung 2003) play a relevant role in political processes by mobilizing politically engaged citizen or by monitoring the performance of governments, but they contribute little to the democratic schooling of citizens, or at least not in the adult population.

Open Access This article is distributed under the terms of the Creative Commons Attribution License which permits any use, distribution, and reproduction in any medium, provided the original author(s) and the source are credited.

\section{References}

Adman, P. \& Stromblad, P. (2013). Political trust as modest expectations: Exploring immigrants' falling confidence in Swedish political institutions. Working paper 2013|6. Linnaeus University: Labour Market and Discrimination Studies.

Almond, G. A., \& Verba, S. (1965). The civic culture: Political attitudes and democracy in five nations. Boston: Little, Brown.

Armingeon, K. (2007). Political participation and associational involvement. In J. Van Deth, J. R. Montero, \& A. Westholm (Eds.), Citizenship and involvement in European democracies: A comparative analysis. Oxon: Routledge.

Ayala, L. J. (2000). Trained for democracy: The differing effects of voluntary and involuntary organizations on political participation. Political Research Quarterly, 53(1), 99-115.

Baggetta, M. (2009). Civic opportunities in associations: Interpersonal interaction, governance experience and institutional relationships. Social Forces, 88(1), 175-199.

Bekkers, R. (2005). Participation in voluntary associations: Relations with resources, personality, and political values. Political Psychology, 26(3), 439-454.

Bradburn, N. M., Rips, L. J., \& Shevell, S. K. (1987). Answering autobiographical questions: The impact of memory and inference on surveys. Science, 236(4798), 157-161.

Burns, N., Schlozman, K. L., \& Verba, S. (2001). The private roots of public action: Gender, equality, and political participation. London: Harvard University Press.

Claassen, R. L. \& Monson J. Q. Does civic education matter? The power of long-term observation and the experimental method. Journal of Political Science Education. (in press).

Coffé, H., \& Geys, B. (2007). Towards an empirical characterization of bridging and bonding social capital. Nonprofit and Voluntary Sector Quarterly, 36(1), 121-139.

Curtis, J. E., Baer, D. E., \& Grabb, E. G. (2001). Nations of joiners: Explaining voluntary association membership in democratic societies. American Sociological Review, 66(6), 783-805.

De Tocqueville, A. (2000 [1835]). Democracy in America. Chicago: University of Chicago Press.

Foley, M. W., \& Edwards, B. (1996). The paradox of civil society. Journal of Democracy, 7(3), 38-52.

Fowler, J. H., Heaney, M. T., Nickerson, D. W., Padgett, J. F., \& Sinclair, B. (2011). Causality in political networks. American Politics Research, 39(2), 437-480. doi:10.1177/1532673x10396310.

Fung, A. (2003). Associations and democracy: Between theories, hopes, and realities. Annual Review of Sociology, 29, 515-539. 
Gesthuizen, M., Van der Meer, T., \& Scheepers, P. (2008). Education and dimensions of social capital: Do educational effects differ due to educational expansion and social security expenditure? European Sociological Review, 24(5), 617-632.

Goldberg, L. R. (1992). The development of markers for the big-five factor structure. Psychological Assessment, 4(1), 26-42.

Halpern, D. (2005). Social capital. Cambridge: Polity Press.

Hill, S. J., Lo, J., Vavreck, L., \& Zaller, J. (2013). How quickly we forget: The duration of persuasion effects from mass communication. Political Communication, 30(4), 521-547.

Hooghe, M. (2003). Value congruence as a causal mechanism for the generation of social capital. In M. Hooghe \& D. Stolle (Eds.), Generating social capital (pp. 89-112). New York: Palgrave.

Hooghe, M., \& Quintelier, E. (2013). Do all associations lead to lower levels of ethnocentrism? A twoyear longitudinal test of the selection and adaptation model. Political Behavior, 35(2), 289-309.

Iglic, H. (2010). Voluntary associations and tolerance: An ambiguous relationship. American Behavioral Scientist, 53(5), 717-736.

Leenheer, J., \& Scherpenzeel, A. C. (2013). Does it pay off to include non-internet households in an internet panel? International Journal of Internet Science, 8(1), 17-29.

Lichterman, P. (2005). Elusive togetherness: Church groups trying to bridge America's divisions. Princeton: Princeton University Press.

Long, J. S., \& Freese, J. (2001). Regression models for categorical dependent variables using Stata. College Station: Stata Press.

McFarland, D. A., \& Thomas, R. J. (2006). Bowling young: How youth voluntary associations influence adult political participation. American Sociological Review, 71(3), 401-425.

Milligan, K., Moretti, E., \& Oreopoulos, P. (2004). Does education improve citizenship? Evidence from the United States and the United Kingdom. Journal of Public Economics, 88(9-10), 1667-1695.

Mondak, J. J., \& Mutz, D. C. (1997). What's so great about league bowling? In Paper presented at the Annual Conference of the Midwest Political Science Association.

Mondak, J. J., Hibbing, M. V., Canache, D., Seligson, M. A., \& Anderson, M. R. (2010). Personality and civic engagement: An integrative framework for the study of trait effects on political behavior. American Political Science Review, 104(01), 85-110. doi:10.1017/S0003055409990359.

Myrberg, G. (2011) When and how does associational affiliation promote political engagement. In Paper presented at the 6th ECPR General Conference, Reykjavik, Iceland. Aug 25-27.

Pattie, C. J., Seyd, P., \& Whiteley, P. (2004). Citizenship in Britain: Values, participation and democracy. Cambridge: Cambridge University Press.

Putnam, R. D. (1993). Making democracy work: Civic traditions in modern Italy. Princeton: Princeton University Press.

Putnam, R. D. (2000). Bowling alone: The collapse and revival of American community. New York: Simon \& Schuster.

Quintelier, E. (2013). Socialization or self-selection? Membership in deliberative associations and political attitudes. Nonprofit and Voluntary Sector Quarterly, 42(1), 174-192.

Rosenblum, N. L. (1998). Membership and morals: The personal uses of pluralism in America. Princeton: Princeton University Press.

Schulz, T., \& Bailer, S. (2012). The impact of organizational attributes on political participation: Results of a multi-level survey from Switzerland. Swiss Political Science Review, 18(1), 1-27.

Selle, P., \& Stromsnes, K. (2001). Membership and democracy. In P. Dekker \& E. M. Uslaner (Eds.), Social capital and participation in everyday life. London: Routledge.

Skocpol, T. (2003). Diminished democracy. Norman: University of Oklahoma Press.

Smith, E. S. (1999). The effects of investments in the social capital of youth on political and civic behavior in young adulthood: A longitudinal analysis. Political Psychology, 20(3), 553-580. doi:10. 1111/0162-895x.00156.

Sobieraj, S., \& White, D. (2004). Taxing political life: Reevaluating the relationship between voluntary association membership, political engagement, and the state. The Sociological Quarterly, 45(4), 739-764.

StataCorp. (2013). Stata user's guide_release 13. College Station: Stata Press.

Stolle, D. (1998). Bowling together, bowling alone: The development of generalized trust in voluntary associations. Political Psychology, 19(3), 497-525.

Stolle, D. (2001). Clubs and congregations: The benefits of joining an association. In K. S. Cook (Ed.), Trust in society (pp. 202-244). New York: Russell Sage Foundation. 
Van der Meer, T. W. G., Walter, A. \& Van Aelst, P. The contingency of voter learning: How election debates influence voters' ability and accuracy of party positions in the 2010 Dutch election campaign. Political Communication. (in press).

Van der Meer, T. W. G., \& Van Ingen, E. (2009). Schools of democracy? Disentangling the relationship between civic participation and political action in 17 European countries. European Journal of Political Research, 40(2), 281-308.

Van Deth, J. (1997). Private groups and public life: Social participation, voluntary associations and political involvement in representative democracies. London: Routledge.

Van Deth, J. (2000). Interesting but irrelevant: Social capital and the saliency of politics in Western Europe. European Journal of Political Research, 37, 115-147.

Van Deth, J. (2006). Democracy and involvement: The benevolent aspects of social participation. In M. Torcal \& J. R. Montero (Eds.), Political disaffection in contemporary democracies. Social capital, institutions, and politics (pp. 101-129). London: Routledge.

Van Ingen, E., \& Bekkers, R. (2015). Generalized trust through civic engagement? Evidence from Five National Panel Studies. Political Psychology, 35(3).

Verba, S., Schlozman, K. L., \& Brady, H. E. (1995). Voice and equality: Civic voluntarism in American politics. Cambridge, Mass: Harvard University Press.

Wollebaek, D., \& Selle, P. (2002). Does participation in voluntary associations contribute to social capital? The impact of intensity, scope, and type. Nonprofit and Voluntary Sector Quarterly, 31, 32-61. 